ARTICLE

\title{
A family of lead clusters with precious metal cores
}

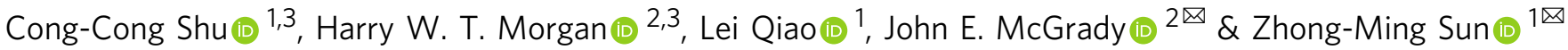

Gold nanoparticles have been used for centuries, both for decoration and in medical applications. More recently, many of the major advances in cluster chemistry have involved welldefined clusters containing tens or hundreds of atoms, either with or without a ligand shell. In this paper we report the synthesis of two gold/lead clusters, $\left[\mathrm{Au}_{8} \mathrm{~Pb}_{33}\right]^{6-}$ and $\left[\mathrm{Au}_{12} \mathrm{~Pb}_{44}\right]^{8-}$, both of which contain nido $\left[\mathrm{Au} @ \mathrm{~Pb}_{11}\right]^{3-}$ icosahedra surrounding a core of $\mathrm{Au}$ atoms. Analogues of these large clusters are not found in the corresponding Ag chemistry: instead, the Ag-centered nido icosahedron, $\left[\mathrm{Ag} @ \mathrm{~Pb}_{11}\right]^{3-}$, is the only isolated product. The structural chemistry, along with the mass spectrometry which shows the existence of $\left[\mathrm{Au}_{2} \mathrm{~Pb}_{11}\right]^{2-}$ but not $\left[\mathrm{Ag}_{2} \mathrm{~Pb}_{11}\right]^{2-}$, leads us to propose that the former species is the key intermediate in the growth of the larger clusters. Density functional theory indicates that secondary $\pi$-type interactions between the $\left[\mathrm{Au} @ \mathrm{~Pb}_{11}\right]^{3-}$ ligands and the gold core play a significant part in stabilizing the larger clusters.

\footnotetext{
${ }^{1}$ Tianjin Key Lab for Rare Earth Materials and Applications, State Key Laboratory of Elemento-Organic Chemistry, School of Materials Science and Engineering, Nankai University, Tianjin 300350, China. ${ }^{2}$ Department of Chemistry, University of Oxford, South Parks Road, Oxford OX1 3QR, UK. ${ }^{3}$ These authors contributed equally: Cong-Cong Shu, Harry W. T. Morgan. ${ }^{凶}$ email: john.mcgrady@chem.ox.ac.uk; sunlab@nankai.edu.cn
} 
G old clusters have long held the attention of chemists, in part because of their often spectacular highly symmetric geometries but also because they have recently found applications in medicine and nanotechnology ${ }^{1,2}$. At one extreme are the naked clusters $\left[\mathrm{Au}_{\mathrm{x}}\right]^{+/ 0 /-}$ which have been studied using a variety of gas-phase spectroscopies ${ }^{3}$ while at the other, thiolatesupported clusters with ever-increasing dimensions continue to emerge. Amongst these, Kornberg's $\mathrm{Au}_{102}\left(\mathrm{~S}_{-} \mathrm{C}_{6} \mathrm{H}_{4}-\mathrm{COOH}\right)_{44}$ and the recently reported $\mathrm{Au}_{279}\left(\mathrm{~S}_{-} \mathrm{C}_{6} \mathrm{H}_{4}{ }^{-} \mathrm{Bu}\right)_{84}$ "Faradaurate-279" are particularly striking examples of how a spherical core of gold atoms can be stabilized by di-, tri- and tetrameric anionic 'staple ligands', $\operatorname{RS}(\mathrm{AuSR})_{\mathrm{n}}(n=1,2,3)$ which constitute a protective 'mantle' around the cluster, ${ }^{4}$. Häkkinen and colleagues have coined the term 'divide and protect' to describe the way that the gold content is separated into a zero-valent $\mathrm{Au}^{0}$ core and monovalent $\mathrm{Au}^{+}$-containing thiolate 'staples', formally anionic 4electron donor ligands that bind to two atoms of the core via lone pairs on the terminal sulfur atoms $s^{6}$. At the core of many of these clusters, it is possible to identify high-symmetry $\mathrm{Au}_{x}$ units, perhaps the most prominent being the 8-electron $\left[\mathrm{Au}_{13}\right]^{5+}$ icosahedron, found, for example, in $\left[\mathrm{Au}_{25}\left(\mathrm{~S}-\mathrm{C}_{6} \mathrm{H}_{4}-\mathrm{COOH}\right)_{18}\right]^{-}$and also in phosphine-ligated systems such as $\left[\mathrm{Au}_{13} \mathrm{Cl}_{2}\left(\mathrm{PMe} \mathrm{Ph}_{10}\right]^{3+7,8}\right.$. Mingos' theoretical work has shown that the relationship between structure and electron count in these and other gold clusters can be understood in terms of overlap of radially directed $s / d_{z^{2}}$ hybrids on each gold atom ${ }^{9,10}$. This model accounts elegantly for the approximately spherical geometries of $\left[\mathrm{Au}_{4}\left(\mathrm{P}^{\mathrm{t}} \mathrm{Bu}_{3}\right)_{4}\right]^{2+}\left(1 \mathrm{~S}^{2}\right)$ and $\left[\mathrm{Au}_{13} \mathrm{Cl}_{2}\left(\mathrm{PMe}_{2} \mathrm{Ph}\right)_{10}\right]^{3+}\left(1 \mathrm{~S}^{2} 1 \mathrm{P}^{6}\right)$ as well as the prolate and oblate distortions found in $\left[\mathrm{Au}_{6}\left(\mathrm{PPh}_{3}\right)_{6}\right]^{2+}\left(1 \mathrm{~S}^{2} 1 \mathrm{P}^{2}\right)$ and $\left[\mathrm{Au}_{7}\left(\mathrm{PPh}_{3}\right)_{7}\right]^{+}$ $\left(1 \mathrm{~S}^{2} 1 \mathrm{P}^{4}\right)$, respectively $\mathrm{y}^{11-13}$. Clusters with 8 gold atoms, in contrast, tend to adopt rather less symmetric structures, such as the 'core + exo' geometries of $\left[\mathrm{Au}_{8}(\mathrm{dppp})_{4}\right]^{2+}$ and $\left[\mathrm{Au}_{8}(\mathrm{dppp})_{4} \mathrm{X}_{2}\right]^{2+}, \mathrm{X}=\mathrm{Cl}^{-}$, $\mathrm{PhC} \equiv \mathrm{C}^{-}$(Fig. 1) where an octahedral $\mathrm{Au}_{6}$ core is capped by two 'exo' gold atoms ${ }^{14,15}$, or the highly distorted cube reported recently for $\left[\mathrm{Au}_{8}\left(\mathrm{PPh}_{3}\right)_{8}\right]^{2+13}$.

In contrast to the well-established chemistry of gold clusters with thiolate or phosphine ligands, there has been only one previous report of a Zintl-ion cluster containing gold, that being the approximately icosahedral 62-electron $\left[\mathrm{Au} @ \mathrm{~Pb}_{12}\right]^{3-}$ reported by some of us in $2017^{16}$. The wider family of endohedral lead clusters

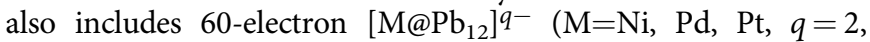
$\mathrm{M}=\mathrm{Co}, \mathrm{Rh}, \mathrm{Ir}, q=3)$ and 58-electron $\left[\mathrm{Mn} @ \mathrm{~Pb}_{12}\right]^{3-17-21}$. The 60electron count has 'magic' status in this family, and also in the analogous clusters of Sn, simply because it corresponds to closedshell configurations at both $\mathrm{M}\left(d^{10}\right)$ and the closo $\left[\mathrm{Pb}_{12}\right]^{2-}$ cage $(4 n+2=50$ where $n$ is the number of vertices), and indeed the empty $\left[\mathrm{Pb}_{12}\right]^{2-}$ cage has itself been identified as a stable entity in the gas phase. Smaller lead cages are also known; for example homometallic $\left[\mathrm{Pb}_{10}\right]^{2-}$ and its nickel-centered analogue $\left[\mathrm{Ni@Pb}{ }_{10}\right]^{2-}$ have both been isolated in the solid state while the heavier group 10 analogues $\left[\mathrm{M} @ \mathrm{~Pb}_{10}\right]^{2-}(\mathrm{M}=\mathrm{Pd}, \mathrm{Pt})$ have been detected in gas-phase experiments ${ }^{17,22,23}$. Even larger clusters such

as $\left[\mathrm{Pd}_{2} \mathrm{Sn}_{18}\right]^{4-24}$, based on fused icosahedral units, are also known, but the Pd-Pd separation in this case is too large to allow for meaningful metal-metal bonding. Examples of Zintl clusters supporting directly bonded transition metals are in fact relatively uncommon, although Sevov's $\left[\mathrm{Ni}_{3} @ \mathrm{Ge}_{18}\right]^{4-}$, Dehnen's $\left[\mathrm{Pd}_{3} @ \mathrm{Sn}_{8} \mathrm{Bi}_{6}\right]^{4-}$ and Fässler's $\left[\mathrm{Au}_{3} \mathrm{Ge}_{18}\right]^{5-}$ are striking examples $^{25-27}$. In this contribution, we report the synthesis, structure and electronic properties of two members of a family of gold/lead clusters, $\left[\mathrm{Au}_{8} \mathrm{~Pb}_{33}\right]^{6-}$ and $\left[\mathrm{Au}_{12} \mathrm{~Pb}_{44}\right]^{8-}$, both isolated as their $[\mathrm{K}([2.2 .2] \text { crypt })]^{+}$salts. Under similar reaction conditions, the corresponding chemistry of $\mathrm{Ag}$ leads only to the smaller $\left[\mathrm{Ag} @ \mathrm{~Pb}_{11}\right]^{3-}$ unit, an observation that naturally raises questions about how the balance between $\mathrm{M}-\mathrm{M}, \mathrm{M}-\mathrm{Pb}$ and $\mathrm{Pb}-\mathrm{Pb}$ bonding controls cluster growth. The wealth of structural data reported here, along with the mass spectrometry of the reaction mixtures and a detailed comparison of the silver and gold chemistry, provides the foundation for a cluster-growth model based on the nido-icosahedral $\mathrm{Au} @ \mathrm{~Pb}_{11}$ unit as the fundamental building block.

\section{Results}

Silver chemistry. The compound $[\mathrm{K}([2.2 .2] \mathrm{crypt})]_{3}\left[\mathrm{Ag} @ \mathrm{~Pb}_{11}\right] \cdot 0.5 \mathrm{en}$, 1 , was synthesized from the reaction of $\mathrm{K}_{4} \mathrm{~Pb}_{9}$ with (AgMes) $)_{4}$ in ethylenediamine (en) solution in the presence of [2.2.2]crypt (full synthetic details are given in the methodology section). Black block-

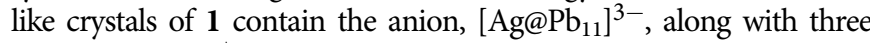
$[\mathrm{K}([2.2 .2] \mathrm{crypt})]^{+}$cations (triclinic space group $\left.P-1\right)$. The anionic component of $1,\left[\mathrm{Ag} @ \mathrm{~Pb}_{11}\right]^{3-}$, shown in Fig. 2, is an approximately $C_{5 v}$-symmetric nido-icosahedron, with the Ag center encapsulated by the $\mathrm{Pb}_{11}$ cluster (the encapsulation is indicated by the "@" in $\left.\left[\mathrm{Ag} @ \mathrm{~Pb}_{11}\right]^{3-}\right)$. The $\mathrm{Ag}-\mathrm{Pb}$ bond lengths to the apical $\mathrm{Pb}(\mathrm{Pb}$ in Fig. 2) and the five $\mathrm{Pb}$ atoms of the open face (Pb7-11 in Fig. 2) are all $\sim 3.01 \AA$ while the distances to $\mathrm{Pb} 2-6$ are somewhat longer at $\sim 3.09 \AA$. The $\mathrm{Pb}-\mathrm{Pb}$ bond lengths vary between 3.15 and $3.30 \AA$, and

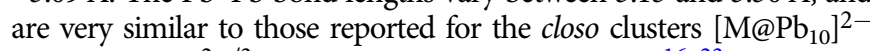

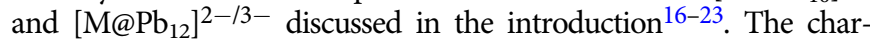
acteristic valence electron count of $48(4 n+4)$ for a nido 11-vertex polyhedron ${ }^{28}$ demands a charge of $4-$ on the $\mathrm{Pb}_{11}$ cluster, consistent with the presence of an $\mathrm{Ag}$ ion in the +1 oxidation state (i.e., $d^{10}$ ). Whilst $\mathbf{1}$ is the only crystalline product obtained from this reaction, the ESI mass spectrum of the reaction mixture (Supplementary Fig. 12) shows prominent peaks for $\left[\mathrm{AgPb}_{10}\right]^{-}$and $\left[\mathrm{AgPb}_{12}\right]^{-}$as well as a somewhat less intense one for $\left[\mathrm{AgPb}_{11}\right]^{-}$itself. The $\left[\mathrm{AgPb}_{10}\right]^{-}$ and $\left[\mathrm{AgPb}_{12}\right]^{-}$ions are most likely both closo species, isoelectronic to the isolated compounds $\left[\mathrm{Ni} @ \mathrm{~Pb}_{10}\right]^{2-}$ and $\left[\mathrm{Pd} @ \mathrm{~Pb}_{12}\right]^{2-}$.

Gold chemistry. The analogous gold chemistry was also carried out using $\mathrm{K}_{4} \mathrm{~Pb}_{9}$ as a source of $\mathrm{Pb}$, but now using $\mathrm{Au}(\mathrm{Mes}) \mathrm{PPh}_{3}$ as the source of the precious metal. Subtle differences in reaction conditions lead to two quite distinct crystalline products, $[\mathrm{K}$ ([2.2.2] crypt $)]_{6}\left[\mathrm{Au}_{8} \mathrm{~Pb}_{33}\right] \cdot$ en $(2)$ and $[\mathrm{K}([2.2 .2] \text { crypt })]_{8}\left[\mathrm{Au}_{12} \mathrm{~Pb}_{44}\right]$ (3). Heating the reagents in en solution in the presence of [2.2.2]

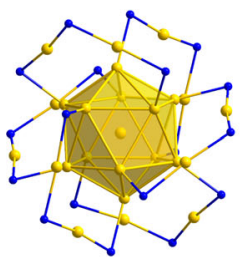

$\left[\mathrm{Au}_{25}(\mathrm{SMe})_{18}\right]^{-}$

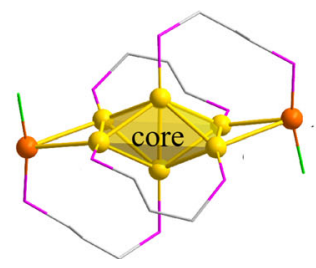

$\left[\mathrm{Au} \mathrm{u}_{8}(\mathrm{dppp})_{4} \mathrm{Cl}_{2}\right]^{2+}$

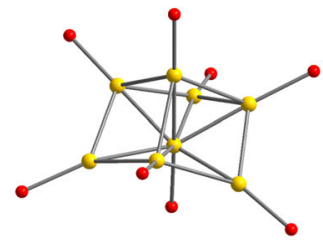

$\left[\mathrm{Au}_{8}\left(\mathrm{PPh}_{3}\right)_{8}\right]^{2+}$

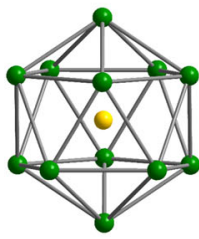

$\left[\mathrm{Au} @ \mathrm{~Pb}_{12}\right]^{3-}$

Fig. 1 Structures of Au-containing clusters. Structural features of selected gold-containing clusters, $\left[\mathrm{Au}_{25}\left(\mathrm{SMe}_{18}\right]^{-},\left[\mathrm{Au}_{8}(\mathrm{dppp})_{4} \mathrm{Cl}_{2}\right]^{2+},\left[\mathrm{Au}_{8}(\mathrm{PPh})_{8}\right]^{2+}\right.$ and $\left[\mathrm{Au} @ \mathrm{~Pb}_{12}\right]^{3-}$. dppp = bis(diphenylphosphino)propane. 

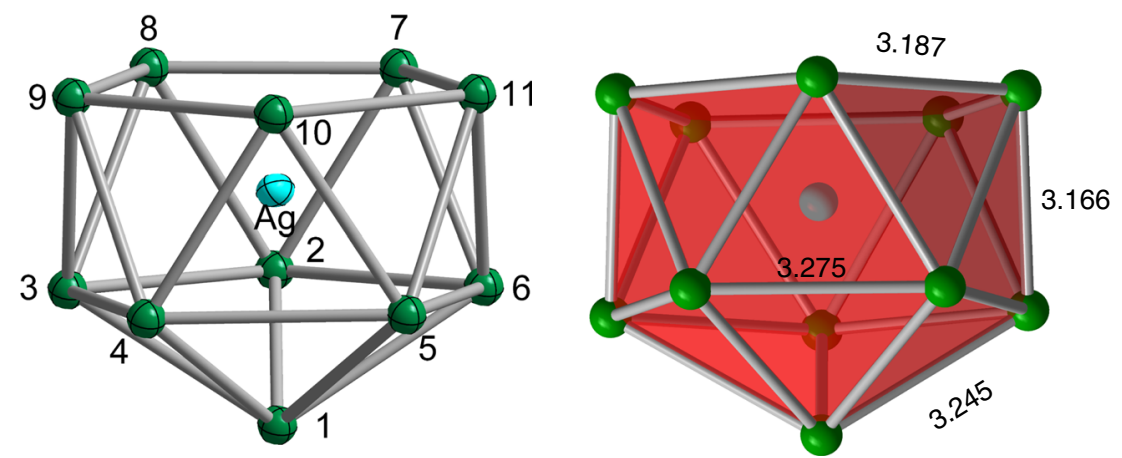

Fig. 2 Structure of the $\left[\mathbf{A g} @ \mathbf{P b}_{\mathbf{1 1}}\right]^{\mathbf{3}-}$ anion in 1. The bond lengths are the average of all symmetry-related Pb-Pb distances. Thermal ellipsoids are set at $50 \%$ probability level.

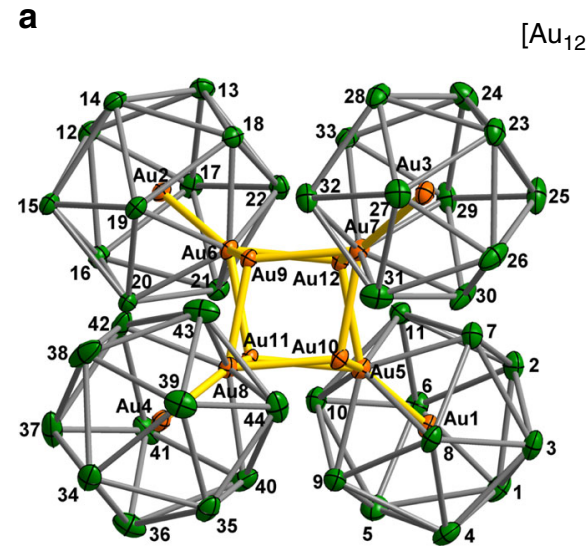

$$
\left[\mathrm{Au}_{12} \mathrm{~Pb}_{44}\right]^{8-}
$$

b
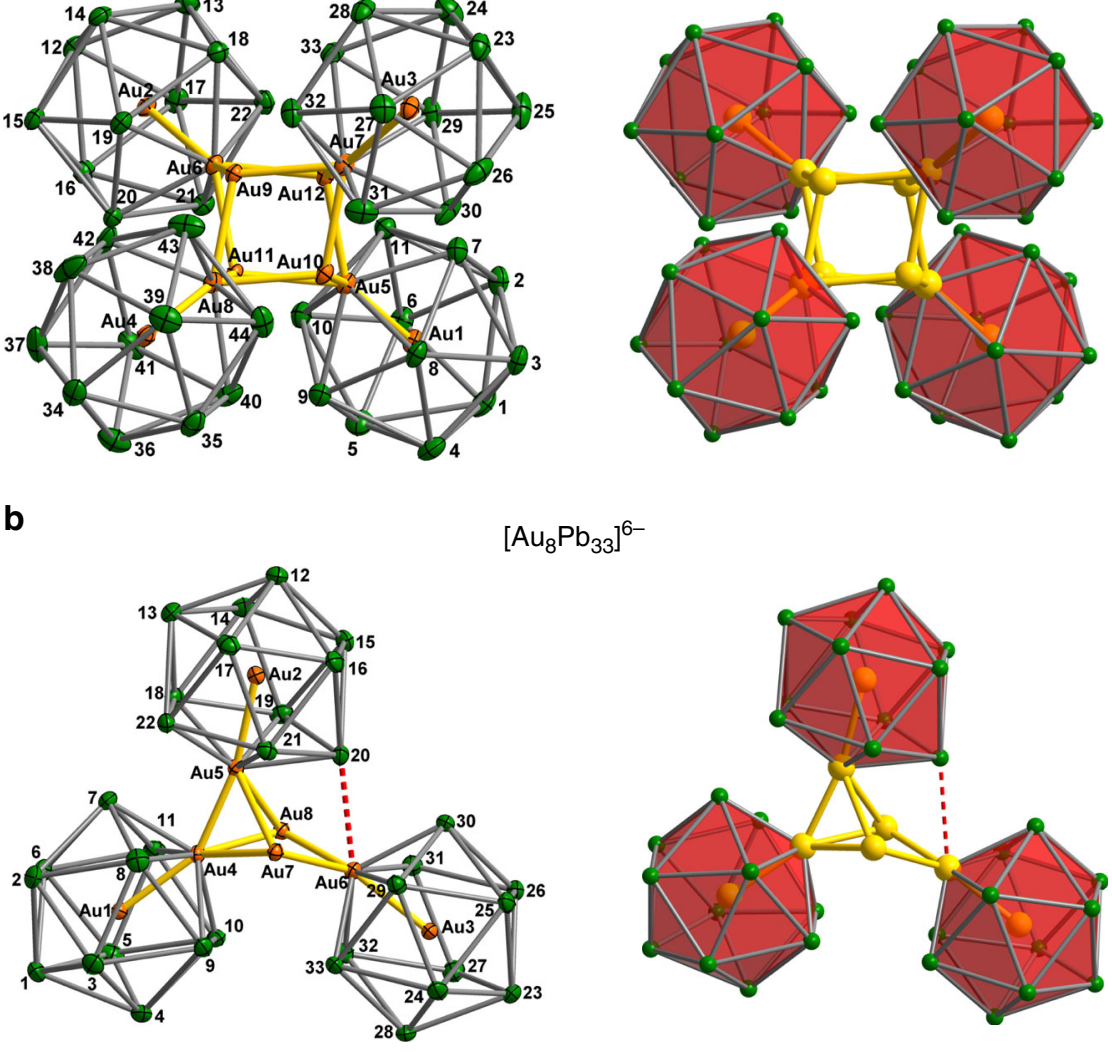

$\left.\mathrm{Au}_{8} \mathrm{~Pb}_{33}\right]^{6-}$

Fig. 3 Structures of $\left[\mathbf{A u}_{\mathbf{1 2}} \mathbf{P b}_{\mathbf{4 4}}\right]^{\mathbf{8}-}$ and $\left[\mathbf{A u}_{\mathbf{8}} \mathbf{P b}_{\mathbf{3 3}}\right]^{\mathbf{6}-}$. a Structure of the $\left[\mathrm{Au}_{12} \mathrm{~Pb}_{44}\right]^{8-}$ anion in $\mathbf{3}$. $\mathbf{b}$ Structure of the $\left[\mathrm{Au}_{8} \mathrm{~Pb}_{33}\right]^{6-}$ anion in $\mathbf{2}$. Thermal ellipsoids are set at the $50 \%$ probability level.

crypt at $60^{\circ} \mathrm{C}$ for $3 \mathrm{~h}$ led to the formation of the smaller cluster, 2 , in $25 \%$ yield (based on $\mathrm{Pb}$ content). If, however, the en solvent is removed and the residue re-dissolved in pyridine followed by further heating $\left(4 \mathrm{~h}\right.$ at $40^{\circ} \mathrm{C}$ ), the larger cluster, 3, is formed in $18 \%$ yield. The structures of the two anionic components of 2 and 3, $\left[\mathrm{Au}_{8} \mathrm{~Pb}_{33}\right]^{6-}$ and $\left[\mathrm{Au}_{12} \mathrm{~Pb}_{44}\right]^{8-}$, respectively, are shown in Fig. 3.

It is immediately striking that the $\mathrm{Au}$ and $\mathrm{Pb}$ content of the clusters is segregated, with an inner $\mathrm{Au}_{\mathrm{x}}$ core surrounded by an outer $\mathrm{Pb}_{\mathrm{y}}$ shell, an observation that is consistent with the low miscibility of the two metals. A closer inspection shows that the two clusters share many common features: both are constructed from $\mathrm{Au}$-centered $\mathrm{Pb}_{11}$ nido-icosahedra $\left(\mathrm{Au} @ \mathrm{~Pb}_{11}\right)$ similar to those found in $\mathbf{1}$, surrounding a core of $\mathrm{Au}$ atoms, $\mathrm{Au}_{5}$ and $\mathrm{Au}_{8}$ in
$\left[\mathrm{Au}_{8} \mathrm{~Pb}_{33}\right]^{6-}$ and $\left[\mathrm{Au}_{12} \mathrm{~Pb}_{44}\right]^{8-}$, respectively. Here and in subsequent discussions, we adopt the nomenclature $[\mathrm{m}, \mathrm{n}]$ to designate a cluster of composition $\left(\left[\mathrm{Au} @ \mathrm{~Pb}_{11}\right]\right)_{\mathrm{m}}(\mathrm{Au})_{\mathrm{n}}$, where $\left[\mathrm{Au}_{8} \mathrm{~Pb}_{33}\right]^{6-}$ and $\left[\mathrm{Au}_{12} \mathrm{~Pb}_{44}\right]^{8-}$ constitute the $[3,5]$ and $[4,8]$ members, respectively. The four $\mathrm{Au} @ \mathrm{~Pb}_{11}$ nido-icosahedra in 3 are remarkably similar to each other, and also to the isolated [Ag@ $\left.\mathrm{Pb}_{11}\right]^{3-}$ cluster: the $\mathrm{Pb}-\mathrm{Pb}$ bond lengths vary between 3.149 (2) and $3.340(2) \AA$, slightly longer, on average, than those in typical $\left[\mathrm{M} @ \mathrm{~Pb}_{12}\right]^{\mathrm{n}-}$ units (3.10-3.20 $\AA$ ) and the eleven $\mathrm{Au}-\mathrm{Pb}$ distances vary between $2.969(2)$ and 3.174(2) $\AA$. Corresponding values in $\left[\mathrm{Au} @ \mathrm{~Pb}_{12}\right]^{3-}$ lie in the range 3.030(9)-3.093(4) $\AA^{16}$. The approximately cubic $\mathrm{Au}_{8}$ core in $\left[\mathrm{Au}_{12} \mathrm{~Pb}_{44}\right]^{8-}$ is shown from two perspectives in Fig. $4 \mathrm{a}$. The $\mathrm{Au}-\mathrm{Au}$ bond lengths are in the range $2.8941(19)-2.943(2) \AA$, broadly comparable to those in 

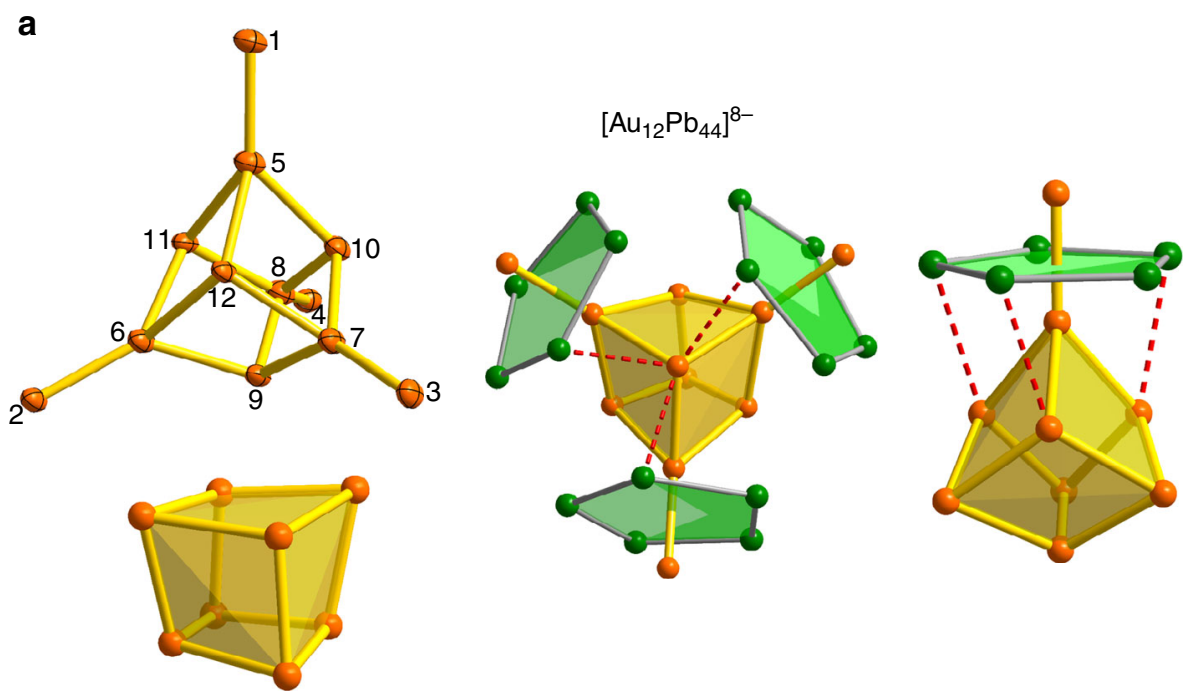

b

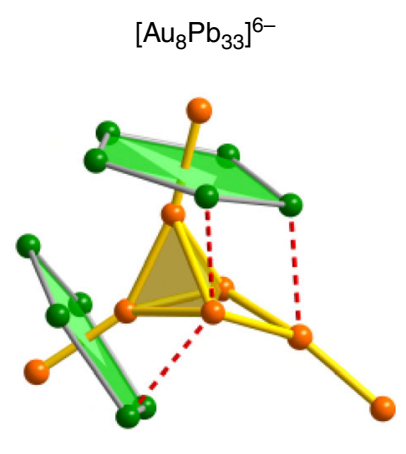

Fig. 4 Structures of the $\mathbf{A} \mathbf{u}_{\mathbf{x}}$ cores in $\left[\mathbf{A u}_{\mathbf{1 2}} \mathbf{P b}_{\mathbf{4 4}}\right]^{\mathbf{8}-}$ and $\left[\mathbf{A u}_{\mathbf{8}} \mathbf{P b _ { 3 3 }}\right]^{\mathbf{6}-}$. a the $A u_{12}$ core in $\left[A u_{12} \mathrm{~Pb}_{44}\right]^{8-}$ and $\mathbf{b}$ the $A u_{8}$ core in $\left[A u_{8} P b_{33}\right]^{6-}$. Red dashed lines emphasize the secondary $\mathrm{Au}$...Pb $\pi$ interactions at $3.60 \AA$ between the capping $\mathrm{Au}$ atoms and the $\mathrm{Pb}_{5}$ rings.

metallic gold $(2.88 \AA)^{29}$, and also in clusters such as $\left[\mathrm{Au}_{3} \mathrm{Ge}_{18}\right]^{5-}$, $\left[\mathrm{Sb}_{3} \mathrm{Au}_{3} \mathrm{Sb}_{3}\right]^{3-}$ and $\left[\mathrm{Au}_{7}(\mathrm{dppp})_{4}\right]^{3+} 27,30,31$. The open $\mathrm{Pb}_{5}$ faces of the nido-icosahedra bind to four corners of the $\mathrm{Au}_{8}$ core (Au5-8, $\mathrm{Au}-\mathrm{Pb}=2.959-3.030 \AA$ ) , leading to short distances of 2.803 (2)-2.821(2) $\AA$ between the endohedral Au (Au1-4) and the Au atom that completes the icosahedral surface (Au5-8). We refer to these four $\mathrm{Au}$ atoms as the 'surface' $\mathrm{Au}$ for this reason. The interactions between the $\mathrm{Au}_{8}$ cube and the nido-icosahedra are not, however, restricted to the four surface $\mathrm{Au}$ atoms directly bound to the open pentagonal faces of the nido icosahedra. There are also numerous secondary contacts between the $\mathrm{Pb}$ atoms of the icosahedra and the four $\mathrm{Au}$ atoms of the $\mathrm{Au}_{8}$ cube that are not bonded directly to the open faces (Au9-12 in Fig. 4-we refer to these as the 'capping' Au atoms). These secondary interactions are shown as dashed red lines in Fig. 4b. The precise bond lengths depend critically on the conformation of the icosahedra, but it is clear that each capping Au atom has secondary contacts at $\sim 3.6 \AA$ with $\mathrm{Pb}$ centers on all three neighboring icosahedra and also that each icosahedron has secondary contacts with all three adjacent capping $\mathrm{Au}$ atoms (Fig. 4, lower panel). Whilst these secondary interactions are $\sim 0.5 \AA$ longer than the $\mathrm{Au}-\mathrm{Pb}$ bonds within the icosahedra, they are sufficiently short and sufficiently numerous to play a significant part in maintaining the integrity of the cluster, as we will show in the subsequent analysis of the electronic structure.

The $\left[\mathrm{Au}_{8} \mathrm{~Pb}_{33}\right]^{6-}$ cluster in $\mathbf{2}$ is rather less symmetric than $\mathbf{3}$, but the icosahedral $\mathrm{Au} @ \mathrm{~Pb}_{11}$ units in the two clusters are very similar. Moreover, the structure of the $\mathrm{Au}_{6} \mathrm{~Pb}_{22}$ fragment (containing Au1,3,4,6,7 and 8 in Figs. 3 and 4) resembles very closely one half of the $\left[\mathrm{Au}_{12} \mathrm{~Pb}_{44}\right]^{8-}$ cluster found in 3 : the $\mathrm{Au}-\mathrm{Au}$ distances are in the region of $2.9 \AA$ and the secondary interactions between the $\mathrm{Pb}$ atoms and the two bridging $\mathrm{Au}$ atoms are again apparent. This structural relationship suggests that $\left[\mathrm{Au}_{8} \mathrm{~Pb}_{33}\right]^{6-}$ can be formulated as a "dimer + monomer" wherein an $\left(\left[\mathrm{Au} @ \mathrm{~Pb}_{11}\right]_{2}\right)\left(\mathrm{Au}_{4}\right)$ unit $($ the $[2,4]$ member of the $[\mathrm{m}, \mathrm{n}]$ series $)$ coalesces with an additional icosahedral $\mathrm{Au} @ \mathrm{AuPb}_{11}$ cluster (the $[1,1]$ member) to form the $[3,5]$ cluster. The $A u @ A u P b_{11}$ icosahedron bridges the $\mathrm{Au}_{4}$ unit of the $[2,4]$ fragment in an $\eta^{2}$ fashion, via both the surface $\mathrm{Au}$ atom, $\mathrm{Au} 5$, and one of the adjacent $\mathrm{Pb}$ atoms, $\mathrm{Pb} 20$. The Au4-Au5 bond is, at 2.7609(12) $\AA$, the shortest $\mathrm{Au}-\mathrm{Au}$ bond in either $\mathbf{2}$ or 3, while the Pb20-Au6 distance of 3.4098(12) $\AA$ is shorter than any of the other secondary interactions. As a result of this strong secondary interaction, $\mathrm{Pb} 20$ is pulled out of the icosahedral surface, leading to four unusually long $\mathrm{Pb}-\mathrm{Pb}$ bonds between 3.30 and $3.40 \AA$.

The ESI mass spectrum of the solution from which $\mathbf{3}$ is isolated (Supplementary Fig. 9) offers some support for the proposal that an $\mathrm{Au}_{2} \mathrm{~Pb}_{11}$ cluster is a common intermediate in the coalescence of the larger clusters. The parent ions of $\mathbf{2}$ and $\mathbf{3}$ lie outside the accessible window for ESI mass spectrometry, but the low-mass region (below $\mathrm{m} / z=3200$ ) shows prominent peaks due to a number of smaller fragments, the most intense of which are $\left[\mathrm{AuPb}_{10}\right]^{-},\left[\mathrm{AuPb}_{11}\right]^{-}$and $\left[\mathrm{AuPb}_{12}\right]^{-}$. Although none of these has been crystallized, we suggest that $\left[\mathrm{AuPb}_{10}\right]^{-}$and $\left[\mathrm{AuPb}_{12}\right]^{-}$

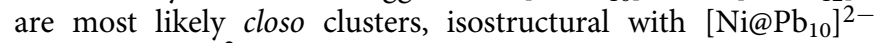
and $\left[\mathrm{Ni@Pb}{ }_{12}\right]^{2-}$, respectively, while $\left[\mathrm{AuPb}_{11}\right]^{-}$is probably 


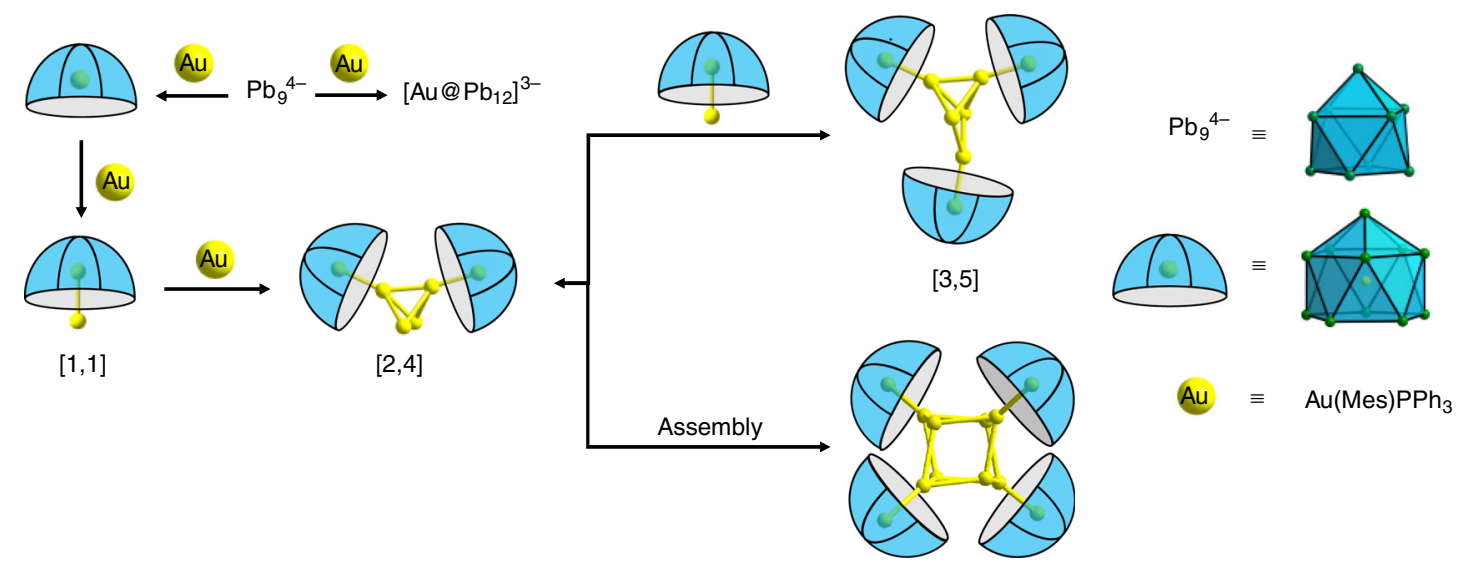

$[4,8]$

Fig. 5 Possible pathways leading to cluster growth. Coalescence of smaller component clusters leads to the assembly of $\left[\mathrm{Au}_{8} \mathrm{~Pb} \mathrm{~b}_{33}\right]^{6-}([3,5])$ and $\left[\mathrm{Au}_{12} \mathrm{~Pb}_{44}\right]^{8-}([4,8])$. The $[1,1],[3,5]$ and $[4,8]$ clusters have been observed, either by X-ray crystallography or ESI-MS.

isostructural with $\mathbf{1}$. There is, however, an additional small peak at $m / z=3088.88$ assigned to $[\mathrm{K}([2.2 .2] \mathrm{crypt})]^{+}\left[\mathrm{Au}_{2} \mathrm{~Pb}_{11}\right]^{2-}$, precisely the composition of the 'monomeric' $[1,1]$ fragment in the structure of 2 , suggesting that binding of an additional $\mathrm{Au}^{+}$ ion to the open face of the nido $\left[\mathrm{AuPb}_{11}\right]^{3-}$ icosahedron is possible. It is significant that there is no corresponding peak for $[\mathrm{K}([2.2 .2] \text { crypt })]^{+}\left[\mathrm{Ag}_{2} \mathrm{~Pb}_{11}\right]^{2-}$ in Supplementary Fig. 12 (it should be found at $m / z=2910.68$ ), indicating that binding of an $\mathrm{Ag}^{+}$ion to the open face of the $\left[\mathrm{Ag} @ \mathrm{~Pb}_{11}\right]^{3-}$ is unfavorable, offering a possible explanation for the absence of $\mathrm{Ag}$ analogues of the larger clusters 2 and 3.

Based on a combination of the structural and ESI mass spectroscopic data, we can speculate on possible mechanistic pathways that control cluster growth (Fig. 5). The nidoicosahedron $\left[\mathrm{M} @ \mathrm{~Pb}_{11}\right]^{3-}$ has been structurally characterized for $\mathrm{M}=\mathrm{Ag}$ and a cluster with the same composition has been observed as a prominent peak in the mass spectrum for $\mathrm{M}=$ $\mathrm{Au}$. It seems reasonable, therefore, to propose $\left[\mathrm{Au} @ \mathrm{~Pb}_{11}\right]^{3-}$ as a likely intermediate in the growth of the larger clusters. The $\left[\mathrm{Au}_{2} \mathrm{~Pb}_{11}\right]^{2-}$ anion observed in the mass spectrum (in combination with a $[\mathrm{K}([2.2 .2] \mathrm{crypt})]^{+}$cation) can then be formed by trapping an $\mathrm{Au}^{+}$cation at the open face of the nido $\left[\mathrm{Au} @ \mathrm{~Pb}_{11}\right]^{3-}$ cluster to complete the $\mathrm{Au}_{2} \mathrm{~Pb}_{11}$ icosahedron that is the basic $[1,1]$ structural unit of both 2 and 3 . In the presence of excess gold (presumably formed by reduction of $\mathrm{Au}^{+}$with $\left.\left[\mathrm{Pb}_{9}\right]^{4-}\right)$, coalescence of two such icosahedra with an $\mathrm{Au}_{2}$ fragment generates the $\left(\left[\mathrm{Au} @ \mathrm{~Pb}_{11}\right]\right)_{2}\left(\mathrm{Au}_{4}\right)$ unit $([2,4])$ that is common to both $\mathbf{2}$ and $\mathbf{3}$. This fragment may then either dimerize to form $3([4,8])$ or react with a third $\left[\mathrm{Au} @ \mathrm{AuPb}_{11}\right]^{2-}$ fragment to form $2([3,5])$. In support of this hypothesis, we have observed that heating an isolated sample of 2 for $3 \mathrm{~h}$ at $60^{\circ} \mathrm{C}$ leads to the formation of 3, presumably via de-coordination of the bridging icosahedron followed by coalescence of two dimer units (Supplementary Fig. 8). A plausible alternative cluster growth pathway might involve the bonding of multiple copies of the fundamental ligand unit, $\left[\mathrm{Au} @ \mathrm{~Pb}_{11}\right]^{3-}$, to pre-formed $\left[\mathrm{Au}_{5}\right]^{3+}$ and $\left[\mathrm{Au}_{8}\right]^{4+}$ clusters to generate 2 and $\mathbf{3}$, respectively. We have, however, found no evidence to support the formation of such large naked gold clusters under the prevailing reaction conditions, so we favor the simpler scheme below where the $A u @ A u P b_{11}$ unit, for which there is experimental evidence, is the common intermediate. In either case, the identity of the dominant isolated product will necessarily be very sensitive to the concentrations of free $\mathrm{Au}$, and so, inevitably, to subtle variations in temperature and solvent polarity.
Electronic structure analysis. In order to gain further insight into the bonding in the anionic clusters in 1, 2 and 3 , and the possible pathways that lead to their formation, we have turned to density functional theory. In Fig. 5 we proposed the $\left[\mathrm{Au} @ \mathrm{~Pb}_{11}\right]^{3-}$ unit as the initial product of the reaction between $\mathrm{Au}(\mathrm{Mes}) \mathrm{PPh}_{3}$ and $\mathrm{K}_{4} \mathrm{~Pb}_{9}$, based on the twin observations that (a) the corresponding mono-anion is present in the mass spectrum and (b) the Ag analogue can be isolated in the solid state. This makes the isolated $\left[\mathrm{M} @ \mathrm{~Pb}_{11}\right]^{3-}$ units a logical place to start our analysis of the electronic structure. The optimized structures of $\left[\mathrm{Ag} @ \mathrm{~Pb}_{11}\right]^{3-}$ and $\left[\mathrm{Au} @ \mathrm{~Pb}_{11}\right]^{3-}$ shown in Fig. 6 are rigorously $C_{5 \mathrm{v}}$ symmetric, with the group 11 metal endohedrally encapsulated in both cases. Alternative structures where the group 11 metal occupies a site on the surface of the cluster, completing an empty $\left[\mathrm{MPb}_{11}\right]^{3-}$ icosahedron, prove to be marginally less stable for both $\mathrm{Ag}$ and $\mathrm{Au}$ (see exo-[ $\left[\mathrm{MPb}_{11}\right]^{3-}$ in Supplementary Table 6). For $\left[\mathrm{Ag@Pb_{11 }}\right]^{3-}$, where crystallographic data are available as a benchmark, the $\mathrm{Ag}-\mathrm{Pb}$ and $\mathrm{Pb}-\mathrm{Pb}$ bonds are overestimated by $\sim 0.1$ A: this is a common observation in highly anionic clusters of this type, and probably reflects the fact that the confining influence of the cationic lattice is modeled only by a high-dielectric continuum in the computational experiment. The important frontier orbitals of $\left[\mathrm{Au} @ \mathrm{~Pb}_{11}\right]^{3-}$, also shown in Fig. 6, are dominated by $\mathrm{Pb} 5 p$ character on the open face of the nido cluster. The HOMO-4 is totally symmetric $\left(a_{1}\right)$ while the HOMO/HOMO-1 is a degenerate pair $\left(e_{1}\right)$. The fragment is isolobal to the $\left[\mathrm{C}_{5} \mathrm{H}_{5}\right]^{-}$ligand and also to nido- $\left[\mathrm{B}_{11} \mathrm{H}_{11}\right]^{4-}$, the coordination chemistry of which is well established through complexes such as $\left[\left(\eta^{5}-\mathrm{B}_{11} \mathrm{H}_{11}\right)_{2} \mathrm{Ni}\right]^{4-32}$, and has the capacity to act as a 6-electron donor to the $\mathrm{Au}_{\mathrm{x}}$ core. The optimized structure of $\left[\mathrm{Au} @ \mathrm{AuPb}_{11}\right]^{2-}$ is also $C_{5 \mathrm{v}}$-symmetric with an $\mathrm{Au}-\mathrm{Au}$ distance of $2.75 \AA$, very similar to those in all the icosahedral units in $\left[\mathrm{Au}_{8} \mathrm{~Pb}_{33}\right]^{6-}$ and $\left[\mathrm{Au}_{12} \mathrm{~Pb}_{44}\right]^{8-}$. The bond orders between the surface $\mathrm{Au}^{+}$ion and the $\mathrm{Pb}$ atoms of the open face are 0.25, compared to values between 0.08 and 0.24 for $\mathrm{Au}-\mathrm{Pb}$ bonds to the endohedrally encapsulated $\mathrm{Au}^{+}$ion. By contrast, the $\mathrm{Au}-\mathrm{Au}$ bond order is only 0.05 , suggesting that direct $\mathrm{Au}-\mathrm{Au}$ bonding within the icosahedron is relatively weak despite the short $\mathrm{Au}-\mathrm{Au}$ distance: this is consistent with a closed-shell $d^{10}$ configuration at both metals. The Kohn-Sham interaction diagram in Fig. 6 summarizes the key features of the interaction of the $\mathrm{Au}^{+}$cation with the nido $\left[\mathrm{Au} @ \mathrm{~Pb}_{11}\right]^{3-}$ fragment. The bonding is dominated by orbitals of local $\sigma$ symmetry $\left(\mathrm{a}_{1}\right.$ in $\left.C_{5 \mathrm{v}}\right)$, i.e., the donation of charge from the HOMO-4 of $\left[\mathrm{Au} @ \mathrm{~Pb}_{11}\right]^{3-}$ to the $6 s$ orbital of $\mathrm{Au}^{+}$. The doubly degenerate HOMO/HOMO-1 (e $\left.e_{1}\right)$ has $\pi$ 


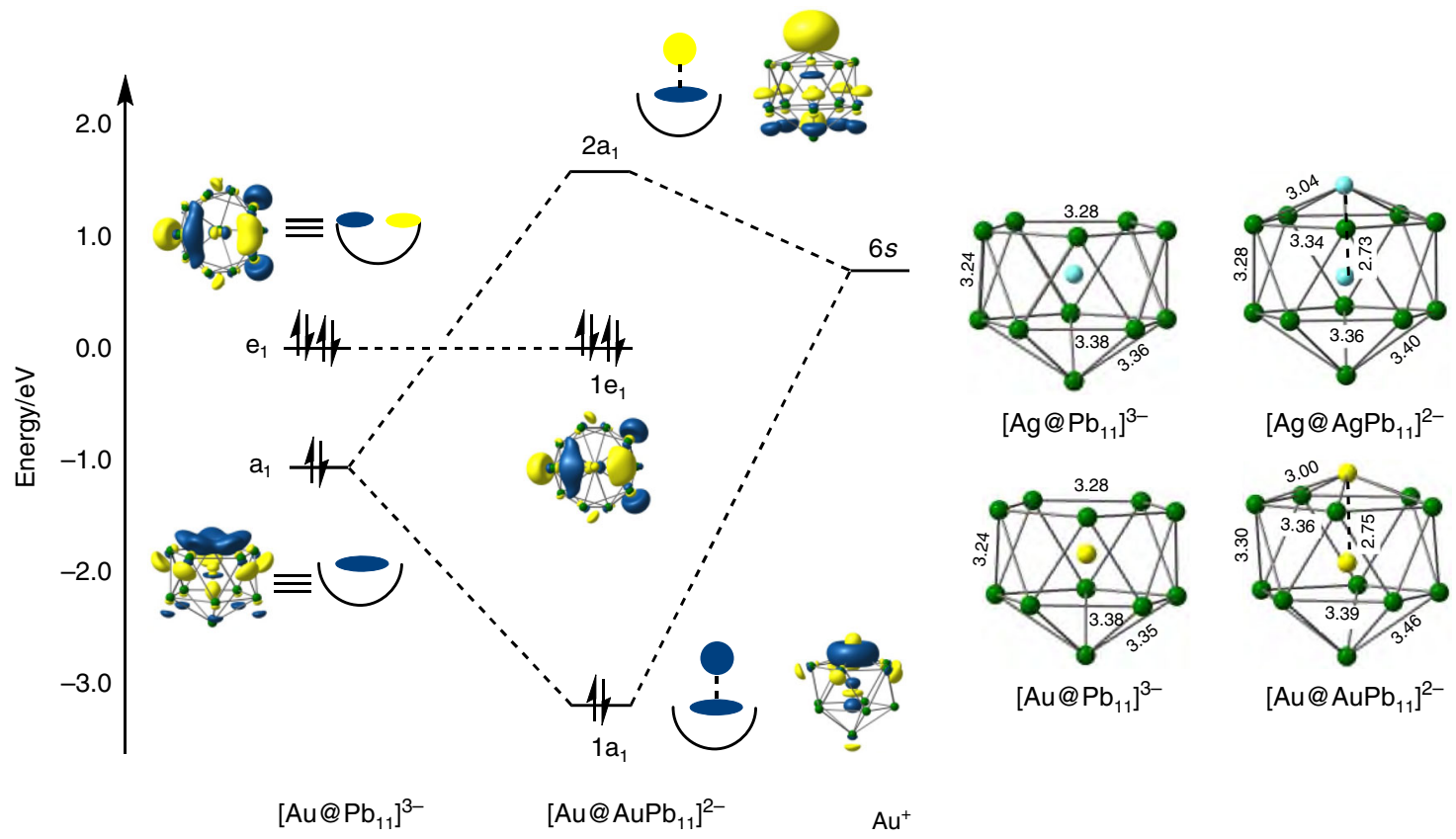

Fig. 6 Electronic structure analysis of $\left[\mathbf{M} @ \mathbf{P b}_{11}\right]^{\mathbf{3}-}$ and $\left[\mathbf{M} @ \mathbf{M P \mathbf { P } _ { 1 1 }}\right]^{\mathbf{2}-}$. Optimized structures of $\left[\mathrm{M} @ \mathrm{~Pb}_{11}\right]^{3-}$ and $\left[\mathrm{M} @ \mathrm{MPb} \mathrm{b}_{11}\right]^{2-}$, and a Kohn-Sham molecular orbital diagram showing the interaction between $\mathrm{Au}^{+}$and the nido-icosahedral fragment $\left[\mathrm{Au} @ \mathrm{~Pb}_{11}\right]^{3-}$. The doubly degenerate $\mathrm{e}_{1}$ orbitals are viewed down the principal axis.

symmetry with respect to the fivefold rotational axis, but it plays no part in the bonding due to the absence of vacant orbitals of appropriate symmetry on $\mathrm{Au}^{+}$. The $1 \mathrm{e}_{1} \mathrm{HOMO}$ therefore remains non-bonding and high in energy even after binding of the surface $\mathrm{Au}^{+}$ion: we will show later that the continuing availability of this doubly degenerate orbital is vital to the formation of the secondary $\mathrm{Au}-\mathrm{Pb}$ bonds. The typical valence electron count for a closo icosahedron is 50, made up of 26 skeletal electrons and 24 radially directed lone pair electrons, 2 on each vertex. The count for $\left[\mathrm{Au} @ \mathrm{AuPb}_{11}\right]^{2-}$, in contrast, is only 48, and it is clear from Fig. 6 that the 'missing' pair of electrons is taken from a radially directed hybrid with dominant $\mathrm{Au} 6 s$ character (the $2 \mathrm{a}_{1}$ LUMO) rather than a skeletal bonding orbital, and so the closo count of 26 remains intact. In this sense $\left[\mathrm{Au} @ \mathrm{AuPb}_{11}\right]^{2-}$ can be viewed either as a nido $\left[\mathrm{Au} @ \mathrm{~Pb}_{11}\right]^{3-}$ cluster capped by an $\mathrm{Au}^{+}$cation or as a closo $\mathrm{Au@AuPb} \mathrm{B}_{11}$ icosahedron with a missing lone pair-both perspectives are consistent with an electron count of 48 . We can quantify the energetic significance of the interactions within $a_{1}$ symmetry by performing an energy decomposition analysis based on the fragmentation of $\left[\mathrm{Au} @ \mathrm{AuPb}_{11}\right]^{2-}$ into $\left[\mathrm{Au} @ \mathrm{~Pb}_{11}\right]^{3-}$ and $\mathrm{Au}^{+}$(see Supplementary Table 7 for details). This indicates an energetic contribution of $-4.58 \mathrm{eV}$ for the interaction in [Au@AuPb $\left.\mathrm{Au}_{11}\right]^{2-}$ compared to only $-2.87 \mathrm{eV}$ in the Ag analogue, $\left[\mathrm{Ag} @ \mathrm{AgPb}_{11}\right]^{2-}$. The difference of almost $2 \mathrm{eV}$ reflects the strong relativistic stabilization of the $6 s$ orbital in $\mathrm{Au}$, and the weak binding of $\mathrm{Ag}^{+}$to the open face may, ultimately, be the underlying cause of the absence of larger clusters in the Ag chemistry.

The important features of the bonding in the larger clusters are most easily approached through an analysis of $\left[\mathrm{Au}_{12} \mathrm{~Pb}_{44}\right]^{8-}$, where the relatively high symmetry simplifies the interpretation of the electronic structure. The cluster in the crystal is approximately $D_{2 \mathrm{~d}}$ symmetric, but small deviations inevitably arise due to the low symmetry of the crystalline environment. We have, therefore, adjusted the coordinates to impose strict $D_{2 \mathrm{~d}}$ symmetry in a structure that is closest, in a least-squares sense, to the geometry of the cluster in the crystal (see Supplementary Fig. 16 for details). Given the overestimation of $\mathrm{Pb}-\mathrm{Pb}$ bond lengths that we encountered for the tri-anionic $\left[\mathrm{Ag} @ \mathrm{~Pb}_{11}\right]^{3-}$ cluster, we have made no attempt to further optimize the structure of $\left[\mathrm{Au}_{12} \mathrm{~Pb}_{44}\right]^{8-}$. Single point calculations on the $D_{2 \mathrm{~d}^{-}}$ symmetrized structure indicate the presence of a near degenerate triplet of orbitals, $\mathrm{e}+\mathrm{b}_{2}$, in the frontier region, over which two electrons are distributed (Fig. 7). The near degeneracy arises because the $\mathrm{Au}_{8}$ core is not strongly distorted from a perfect tetrahedron, in which limit the $\mathrm{e}+\mathrm{b}_{2}$ manifold correlates with triply degenerate $t_{2}$. By distributing two electrons over these three orbitals we can converge on two triplet states, ${ }^{3} \mathrm{~A}_{2}$ and ${ }^{3} \mathrm{E},\left(\mathrm{e}^{2}\right.$ and $\mathrm{e}^{1} \mathrm{~b}^{1}$ configurations, respectively) and a closed-shell singlet $\left({ }^{1} \mathrm{~A}_{1}\right.$, $\mathrm{b}_{2}{ }^{2}$ ), all of which lie within $0.03 \mathrm{eV}$. Given the well-documented limitations of DFT in identifying ground-state multiplicities ${ }^{33,34}$, these energies are too close to allow for a definitive conclusion on the ground spin state of $\left[\mathrm{Au}_{12} \mathrm{~Pb}_{44}\right]^{8-}$. The following analysis is based on the singlet, although very similar features emerge in the other two low-lying states. The bond orders for the $\mathrm{Au}-\mathrm{Au}$ and $\mathrm{Au}-\mathrm{Pb}$ bonds within the individual icosahedra are very similar to those in the isolated $\left[\mathrm{Au} @ \mathrm{AuPb}_{11}\right]^{2-}$ fragment $(\sim 0.06$ and $\sim 0.13-0.16$, respectively). Perhaps more surprisingly, bond orders for the $\mathrm{Au}-\mathrm{Au}$ bonds within the $\mathrm{Au}_{8}$ cube are also small (0.09-0.13), and in fact are of similar magnitude to the secondary $\mathrm{Au}-\mathrm{Pb}$ interactions between the icosahedra and the capping $\mathrm{Au}$ atoms alluded to previously (0.08-0.11). Given the large number of these secondary interactions (on average, 3 per capping $\mathrm{Au}$ atom, 3 per icosahedron, Fig. 4), it seems likely that they are more influential in determining the structure than direct $\mathrm{Au}-\mathrm{Au}$ bonding. This might account for the very different structure adopted by the $\left[\mathrm{Au}_{8}\right]^{4+}$ core in 2 compared to the bicapped octahedral in $\left[\mathrm{Au}_{8}(\mathrm{dppp})_{4} \mathrm{X}_{2}\right]^{2+15}$, where $\mathrm{Au}-\mathrm{Au}$ bonding is clearly the dominant structural influence.

A schematic molecular orbital diagram where the cluster is decomposed into four nido $\left[\mathrm{Au} @ \mathrm{~Pb}_{11}\right]^{3-}$ ligands and an approximately cubic $\left[\mathrm{Au}_{8}\right]^{4+}$ core is presented in Fig. 7 . The calculations were performed in $D_{2 \mathrm{~d}}$ symmetry, and a full analysis is presented in the Supplementary Figs. 16 and 17 and Supplementary Table 8 , but for the sake of clarity we find it convenient here to adopt the symmetry labels of the higher $T_{\mathrm{d}}$ 


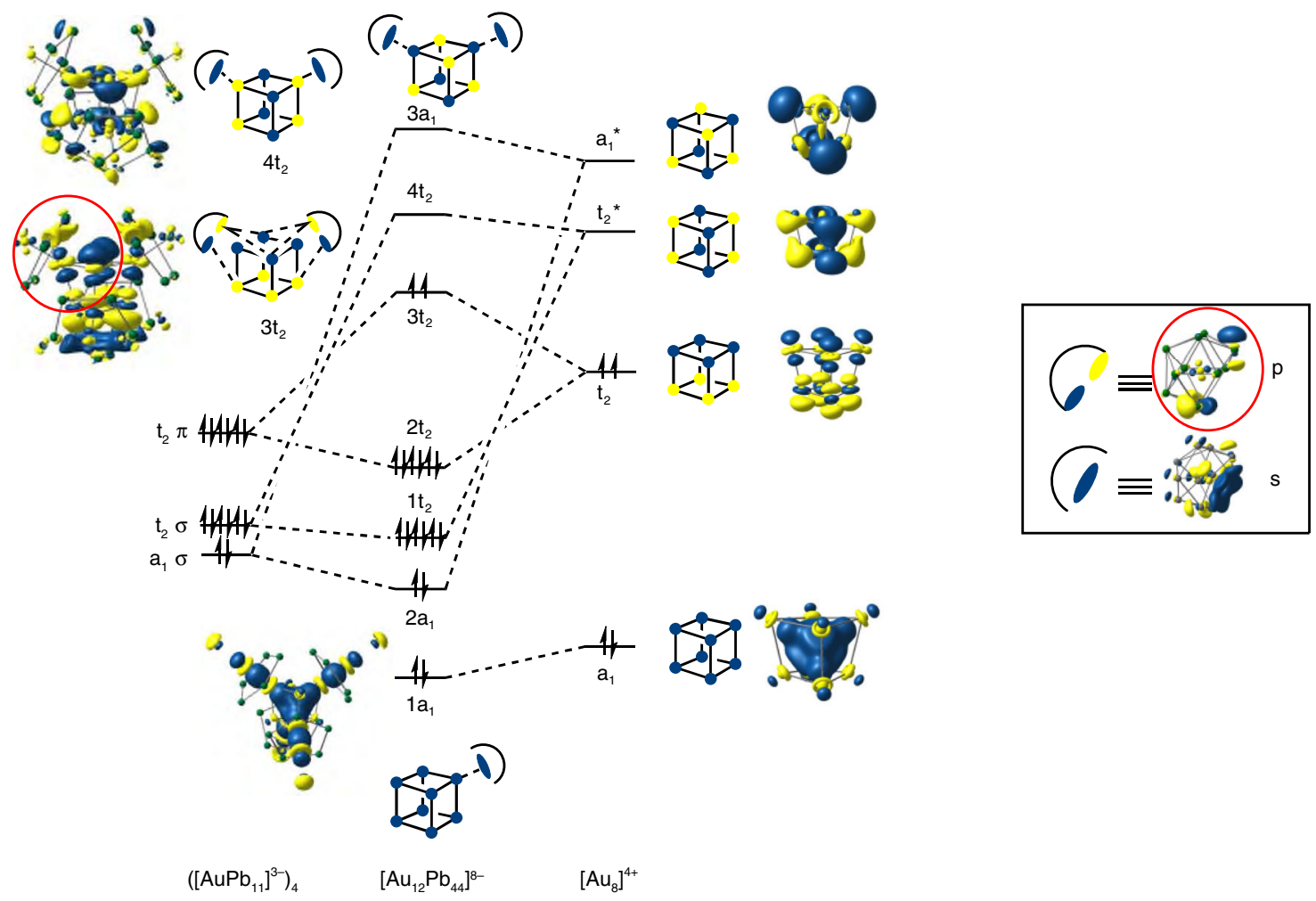

Fig. 7 Electronic structure of $\left[\mathbf{A u}_{\mathbf{1 2}} \mathbf{P b}_{\mathbf{4 4}}\right]^{\mathbf{8}-}$. Schematic $\mathrm{MO}$ diagrams for $\left[\mathrm{Au}_{12} \mathrm{~Pb}_{44}\right]^{8-}$, with orbitals labeled according to $T_{d}$ point symmetry. The majority of the $\mathrm{Pb}$ atoms have been removed from the iso-surface plots for clarity. Cartoon depictions of the orbitals are provided to guide the eye.

point group. The frontier region for the $\left[\mathrm{Au}_{8}\right]^{4+}$ fragment can be understood in terms of the interactions of $8 s / d_{z^{2}}$ hybrids, which generate bonding and antibonding linear combinations, $\mathrm{a}_{1} / \mathrm{a}_{1}$ * and $t_{2} / t_{2}{ }^{*}$. The bonding $a_{1}$ orbital is strongly stabilized and doubly occupied, and this pair of electrons is primarily responsible for the integrity of the $\mathrm{Au}_{8}$ unit in $\left[\mathrm{Au}_{8}\right]^{4+}$ and also in 3 itself. The remaining two valence electrons then occupy the $t_{2}$ orbital, driving a first-order Jahn-Teller instability which accounts for the slight distortion of the $\mathrm{Au}_{8}$ core in $\left[\mathrm{Au}_{12} \mathrm{~Pb}_{44}\right]^{8-}$ from perfect tetrahedral symmetry. This distortion is, however, a minor feature that does not negate the value of presenting the analysis in the higher point group. When the four nido $\left[\mathrm{Au} @ \mathrm{~Pb}_{11}\right]^{3-}$ ligands are introduced, we can identify two distinct types of interactions with the $\left[\mathrm{Au}_{8}\right]^{4+}$ cluster (see inset in Fig. 7). First, the HOMO-4 of the ligands $\left(a_{1}\right.$ in Fig. 6$)$ generate linear combinations $\left(a_{1}+t_{2}\right)$ with local $\sigma$ symmetry that can overlap directly with the corresponding linear combinations of $s / d_{z^{2}}$ hybrids on the $\mathrm{Au}$ atoms bonded directly to the open $\mathrm{Pb}_{5}$ faces, in precisely the same way as the $s /$ $d_{z^{2}}$ hybrid on the single $\mathrm{Au}$ atom did in $\left[\mathrm{Au}_{2} @ \mathrm{~Pb}_{11}\right]^{2-}$ (see the cartoon representations of the $3 \mathrm{a}_{1}$ and $4 \mathrm{t}_{2}$ orbitals in Fig. 7 ). The second mechanism involves the doubly degenerate $\mathrm{HOMO} /$ HOMO- 1 of the ligand which has local $\pi$ symmetry and generates linear combinations of $e+t_{1}+t_{2}$ symmetry, the last of which can overlap with a $t_{2}$-symmetric linear combinations of $s / d_{z^{2}}$ hybrids on the three adjacent capping $\mathrm{Au}$ atoms. The $\pi$ character of this pathway is shown in the cartoon representation of the $3 t_{2}$ orbital of $\left[\mathrm{Au}_{12} \mathrm{~Pb}_{44}\right]^{8-}$ in Fig. 7, and the contours of the corresponding isosurface on the nido $\left[\mathrm{Au} @ \mathrm{~Pb}_{11}\right]^{3-}$ ligands (highlighted in the red circles in Fig. 7), show the clear fingerprint of the HOMO/ HOMO- 1 . The bonding of the $\left[\mathrm{Au} @ \mathrm{~Pb}_{11}\right]^{3-}$ ligand to the $\mathrm{Au}_{8}$ core is therefore made up of two quite distinct components- $\sigma$ bonding to the $\mathrm{Au}$ atoms that bind to the center of the $\mathrm{Pb}_{5}$ faces and secondary $\pi$ bonding to the three adjacent capping Au atoms. We can estimate the relative importance of the two components by performing an energy decomposition analysis, noting that the $\sigma$-type interactions are mediated primarily by the $\mathrm{a}_{1}{ }^{*}$ and $\mathrm{t}_{2}{ }^{*}$ orbitals of the $\mathrm{Au}_{8}$ core while the $\pi$-type interactions involve primarily the partially occupied $t_{2}$ orbital. By successively removing virtual fragment orbitals from the basis (using the removefragorbitals option in $\mathrm{ADF}$ ), we can therefore associate distinct energetic contributions to the $\sigma$ and $\pi$ pathways. Eliminating the four virtual orbitals on $\left[\mathrm{Au}_{8}\right]^{4+}$ that mediate the $\sigma$ pathway $\left(\mathrm{a}_{1}{ }^{*}\right.$ and $\left.\mathrm{t}_{2}{ }^{*}\right)$ reduces the total interaction energy by $2.4 \mathrm{eV}$, while further closing down the secondary $\pi$ pathway by eliminating the two unoccupied components of $t_{2}$ leads to an additional loss of $3.2 \mathrm{eV}$. By this measure, it appears, therefore, that the secondary $\pi$-type interactions make a dominant contribution to the overall stability of the cluster: they are particularly strong because they allow for electron transfer from the high-energy $\mathrm{HOMO}$ and $\mathrm{HOMO}-1$ of the ligand to the $\mathrm{Au}_{8}$ core.

\section{Discussion}

The common structural elements of the two Au clusters reported here, $\left[\mathrm{Au}_{8} \mathrm{~Pb}_{33}\right]^{6-}$ and $\left[\mathrm{Au}_{12} \mathrm{~Pb}_{44}\right]^{8-}$, suggest that both are formed by fusion of icosahedral $\left[\mathrm{Au} @ \mathrm{~Pb}_{11} \mathrm{Au}\right]^{2-}$ fragments which can, in turn, be generated from the precursor ligand $\left[\mathrm{Au} @ \mathrm{~Pb}_{11}\right]^{3-}$ by trapping of $\mathrm{Au}^{+}$. Although neither of these smaller fragments has

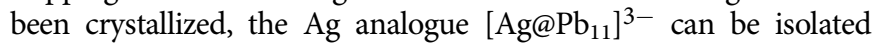
from the corresponding reactions with (AgMes) $)_{4}$, while fragments corresponding to both $\left[\mathrm{Au} @ \mathrm{~Pb}_{11}\right]^{-}$and $\left[\mathrm{Au}_{2} \mathrm{~Pb}_{11}\right]^{-}$have been observed by mass spectrometry. In contrast we find no evidence for the formation of $\left[\mathrm{Ag}_{2} \mathrm{~Pb}_{11}\right]^{-}$and we suspect that the instability of this species is the root cause of the absence of larger silver/lead 
clusters. The bonding of the nido $\left[\mathrm{Au} @ \mathrm{~Pb}_{11}\right]^{3-}$ ligands to the $\left[\mathrm{Au}_{8}\right]^{4+}$ core of $\mathbf{2}$ is made up of two distinct components: one $\mathrm{Au}$ is bound to the center of the open $\mathrm{Pb}_{5}$ face through a $\sigma$-symmetric interaction while orbitals of $\pi$ symmetry interact with the three adjacent $\mathrm{Au}$ atoms. Overall, then, each $\left[\mathrm{Au} @ \mathrm{~Pb}_{11}\right]^{3-}$ ligand has bonding interactions with four $\mathrm{Au}$ atoms of the core. Density functional theory indicates that the secondary interactions are very significant energetically, and in fact contribute more to the integrity of the cluster than direct $\mathrm{Au}-\mathrm{Au}$ bonding. The importance of these secondary $\pi$-type $\mathrm{Pb}$...Au interactions presents an interesting parallel to gold thiolate cluster family, where the 'divide and protect' model has anionic 'staple' ligands containing $\left[(\mathrm{RS}) \mathrm{Au}^{+}(\mathrm{SR})\right]^{-}$and $\left[(\mathrm{RS}) \mathrm{Au}^{+}(\mathrm{SR}) \mathrm{Au}^{+}(\mathrm{SR})\right]^{-}$binding to the zerovalent $\mathrm{Au}_{\mathrm{x}}$ core via two terminal sulfurs. In the $\mathrm{Au} / \mathrm{Pb}$ cluster family, the $\left[\mathrm{Au} @ \mathrm{~Pb}_{11}\right]^{3-}$ ligands play a similar role in that they bind to the $\mathrm{Au}_{n}$ core $(n=$ 5 and 8 in $\left[\mathrm{Au}_{8} \mathrm{~Pb}_{33}\right]^{6-}$ and $\left[\mathrm{Au}_{12} \mathrm{~Pb}_{44}\right]^{8-}$, respectively) via the open $\mathrm{Pb}_{5}$ face of the nido $\mathrm{Pb}_{11}$ units. The cluster growth model shown in Fig. 5 allows us to speculate on what other members of the $\mathrm{Au} / \mathrm{Pb}$ family might be accessible. The next obvious stages in cluster growth would be the $[5,11]$ cluster, a hexa-capped trigonal bipyramid with overall composite $\left[\mathrm{Au}_{16} \mathrm{~Pb}_{55}\right]^{10-}$, and a $[6,14]$ octa-capped octahedron, $\left[\mathrm{Au}_{20} \mathrm{~Pb}_{66}\right]^{12-}$. Whilst the progressive 2increase in anionic charge at each step will certainly terminate the series before very large gold cores can be reached, these larger clusters may be accessible under reducing conditions where $\mathrm{Au}$ is present in excess.

\section{Methods}

Synthesis of $[K([2.2 .2] c r y p t)]_{3}\left[\mathbf{A g} @ \mathbf{P b}_{11}\right] \cdot 0.5 e n(1)$. In a $10 \mathrm{~mL}$ vial, $150 \mathrm{mg}$ $(0.074 \mathrm{mmol})$ of $\mathrm{K}_{4} \mathrm{~Pb}_{9}$ and $100 \mathrm{mg}(0.27 \mathrm{mmol})$ of $4,7,13,16,21,24$-hexaoxa-1,10 diazabicyclo[8.8.8] hexacosane (abbreviated henceforth as [2.2.2]crypt) were dissolved in ethylenediamine $(2.5 \mathrm{~mL})$. After stirring for $1 \mathrm{~h}$, the black-green solution was filtered onto $40 \mathrm{mg}(0.04 \mathrm{mmol})$ of $(\mathrm{AgMes})_{4}$. After $3 \mathrm{~h}$ at room temperature, the resulting deep-black solution was filtered through glass wool and transferred to a test tube. After 15 days, black block-like crystals of $[\mathrm{K}([2.2 .2] \text { crypt })]_{3}[\mathrm{Ag} @ \mathrm{P}$ $\left.b_{11}\right] \cdot 0.5$ en was obtained by layering with toluene $(3 \mathrm{~mL})(25 \%$ crystalline yields based on $\mathrm{Pb}$ ). ESI-MS of the products of the reaction with (AgMes) $)_{4}$ are shown in Supplementary Figs. 12-14. The energy dispersive X-ray (EDX) spectrum of $\mathbf{1}$ is shown in Supplementary Fig. 15. Note: all Ag-related reactions should be protected from light to avoid decompositions.

Synthesis of $[K([2.2 .2] c r y p t)]_{6}\left[\mathbf{A u}_{8} \mathbf{P b}_{33}\right] \cdot e n$ (2). In a $10 \mathrm{~mL}$ vial, $150 \mathrm{mg}$ $(0.074 \mathrm{mmol})$ of $\mathrm{K}_{4} \mathrm{~Pb}_{9}$ and $100 \mathrm{mg}(0.27 \mathrm{mmol})$ of [2.2.2]crypt were dissolved in ethylenediamine $(2.5 \mathrm{~mL})$. In a second vial, $150 \mathrm{mg}(0.25 \mathrm{mmol}) \mathrm{Au}(\mathrm{Mes}) \mathrm{PPh}_{3}$ was dissolved in $0.5 \mathrm{~mL}$ toluene. The toluene solution was added to ethylenediamine solution dropwise while stirring vigorously. After $3 \mathrm{~h}$ at $60^{\circ} \mathrm{C}$, the resulting redblack solution was filtered through glass wool and transferred to a test tube. After 7 days, black plate-like crystals of $[\mathrm{K}([2.2 .2] \mathrm{crypt})]_{6}\left[\mathrm{Au}_{8} \mathrm{~Pb}_{33}\right] \cdot$ en were obtained together with black rod-like crystals of $[\mathrm{K}([2.2 .2] \mathrm{crypt})]_{4}\left[\mathrm{Au}_{4} \mathrm{~Pb}_{22}\right]$ by layering with toluene $(3 \mathrm{~mL})(25 \%$ crystalline total yields based on Pb). ESI-MS of the products of the reaction with $\mathrm{Au}(\mathrm{Mes}) \mathrm{PPh}_{3}$ are shown in Supplementary Figs. 9-11. EDX spectra of $\mathbf{2}$ and $\mathbf{3}$ are shown in Supplementary Fig. 15.

Synthesis of $[K([2.2 .2] c r y p t)]_{8}\left[\mathbf{A u}_{12} \mathbf{P b}_{\mathbf{4 4}}\right]$ (3). In a $10 \mathrm{~mL}$ vial, $150 \mathrm{mg}(0.074$ $\mathrm{mmol})$ of $\mathrm{K}_{4} \mathrm{~Pb}_{9}$ and $100 \mathrm{mg}(0.27 \mathrm{mmol})$ of [2.2.2]crypt were dissolved in ethylenediamine $(2.5 \mathrm{~mL})$. In a second vial, $150 \mathrm{mg}(0.25 \mathrm{mmol}) \mathrm{Au}(\mathrm{Mes}) \mathrm{PPh}_{3}$ was dissolved in $0.5 \mathrm{~mL}$ toluene. The toluene solution was added to ethylenediamine solution dropwise and stirred $3 \mathrm{~h}$ at $60^{\circ} \mathrm{C}$ while stirring vigorously. After removal of the ethylenediamine solvent, the residue was re-dissolved in pyridine $(3 \mathrm{~mL})$ and, after heating for $4 \mathrm{~h}$ at $40^{\circ} \mathrm{C}$, the resulting dark purple solution was filtered through glass wool and transferred to a test tube. After 2 weeks, black block-like crystals of $[\mathrm{K}([2.2 .2] \mathrm{crypt})]_{8}\left[\mathrm{Au}_{12} \mathrm{~Pb}_{44}\right]$ was obtained by layering with toluene $(3 \mathrm{~mL})(18 \%$ crystalline yield based on $\mathrm{Pb})$. In a separate experiment, a crystalline sample of $\mathbf{3}$ was also obtained starting from an isolated sample $(20 \mathrm{mg})$ of $\mathbf{2}$ dissolved in pyridine $(1.0 \mathrm{~mL})$ in an NMR tube. The resulting red-brown solution was heated at $60^{\circ} \mathrm{C}$ for $3 \mathrm{~h}$ and then layered by toluene $(1.0 \mathrm{~mL})$ to allow for crystallization. Black block-like crystals of $[\mathrm{K}([2.2 .2] \text { crypt })]_{8}\left[\mathrm{Au}_{12} \mathrm{~Pb}_{44}\right]$ were isolated after two weeks (25\% yield based on 2 ).

Single crystal X-ray diffraction data analyses. The available data for $\mathbf{1}$ and $\mathbf{2}$ were refined successfully against the structural models, as measured by $R_{1}$ and $w R_{2}$ values of less than 0.07 and 0.18 , respectively. In contrast, all attempts to obtain the high-quality X-ray diffraction data for compound 3 were unsuccessful due to the absorption of the $\mathrm{Cu}$ light source $(\lambda=1.54184 \AA)$ by the $\mathrm{Au}$ and $\mathrm{Pb}$ elements of the cluster and its large unit cell volume. Despite this, one data set of reasonable quality was obtained but still contains a relatively large final $\mathrm{R}$ value of $15.06 \%$. All diffraction methods were carried out at $100 \mathrm{~K}$. A summary of the crystallographic data for these complexes is listed in Supplementary Table 1, and selected bond distances are given in Supplementary Tables 2-4 for compound 1, 2 and 3, respectively. Photographs of the crystals are shown in Supplementary Fig. 1, while unit cells and asymmetric units for 1, 2 and $\mathbf{3}$ are shown in Supplementary Figs. 2-7.

Computational details. All density functional calculations were performed using the Amsterdam Density Functional (ADF) software package, version 2017.1135-37. The Perdew Burke Ernzerhof (PBE) functional ${ }^{38}$ was used in conjunction with a polarized triple-zeta (TZP) basis on $\mathrm{Ag}, \mathrm{Au}$, and $\mathrm{Pb}^{39}$. Core orbitals up to and including $3 \mathrm{~d}(\mathrm{Ag})$ and $4 \mathrm{~d}(\mathrm{Au}, \mathrm{Pb})$ were treated as core for both atoms ("small" core option in ADF). Scalar relativistic corrections were included using the ZeroOrder relativistic approximation (ZORA ${ }^{40-42}$. The confining effects of the cation environment was mimicked using a continuum solvent model with dielectric constant of $78.39^{43}$. Where geometries were optimized, the gradient algorithm of Versluis and Ziegler was employed ${ }^{44}$. The energy decomposition was performed according to the scheme proposed by Ziegler and Rauk (Supplementary Tables 7 and 8$)^{45}$. Bond orders are computed according to the scheme of Nalewajski and Mrozek (Supplementary Table 9) ${ }^{46}$. Full details of the optimized geometries and the geometries used in the single point calculations on $\left[\mathrm{Au}_{12} \mathrm{~Pb}_{44}\right]^{8-}$ are summarized in Supplementary Table 6 and Supplementary Fig. 16. The effects of permuting $\mathrm{Au}$ and $\mathrm{Pb}$ positions in $\left[\mathrm{Au}_{12} \mathrm{~Pb}_{44}\right]^{8-}$ are collected in Supplementary Fig. 17.

\section{Data availability}

The X-ray crystallographic of compounds $\mathbf{1}, \mathbf{2}$, and $\mathbf{3}$ reported in this study have been deposited at the Cambridge Crystallographic Data Centre (CCDC) under deposition numbers 1972423-1972425. These data can be obtained free of charge from the Cambridge Crystallographic Data Centre via www.ccdc.cam.ac.uk/data_request/cif. The authors declare that all other data supporting the findings of this study are available within the paper (and its Supplementary Information files).

Received: 20 February 2020; Accepted: 9 June 2020; Published online: 10 July 2020

\section{References}

1. Li, G. \& Jin, R. Atomically precise gold nanoclusters as new model catalysts. Acc. Chem. Res. 46, 1749-1758 (2013).

2. Qian, H., Zhu, M., Wu, Z. \& Jin, R. Quantum sized gold nanoclusters with atomic precision. Acc. Chem. Res. 45, 1470-1479 (2012).

3. Gruene, P. et al. Structures of neutral $\mathrm{Au}_{7}, \mathrm{Au}_{19}$, and $\mathrm{Au}_{20}$ clusters in the gas phase. Science 321, 674-676 (2008).

4. Higaki, T. et al. Sharp transition from nonmetallic $\mathrm{Au}_{246}$ to metallic $\mathrm{Au}_{279}$ with nascent surface plasmon resonance. J. Am. Chem. Soc. 140, 5691-5695 (2018).

5. Jadzinsky, P. D., Calero, G., Ackerson, C. J., Bushnell, D. A. \& Kornberg, R. D. Structure of a thiol monolayer-protected gold nanoparticle at $1.1 \AA \AA$ resolution. Science 318, 430-433 (2007).

6. Häkkinen, H., Walter, M. \& Gronbeck, H. Divide and protect: capping gold nanoclusters with molecular gold-thiolate rings. J. Phys. Chem. B. 110 9927-9931 (2006).

7. Zhu, M., Aikens, C. M., Hollander, F. J., Schatz, G. C. \& Jin, R. Correlating the crystal structure of a thiol-protected $\mathrm{Au}_{25}$ cluster and optical properties. J. Am. Chem. Soc. 130, 5883-5885 (2008).

8. Briant, C. E. et al. Synthesis and $X$-ray structural characterization of the centred icosahedral gold cluster compound $\left[\mathrm{Au}_{13}\left(\mathrm{PMe}_{2} \mathrm{Ph}\right)_{10} \mathrm{Cl}_{2}\right]\left(\mathrm{PF}_{6}\right)_{3}$; the realization of a theoretical prediction. J. Chem. Soc., Chem. Commun. 5, 201-202 (1981).

9. Mingos, D. M. P. Molecular orbital calculations on cluster compunds of gold. J. Chem. Soc., Dalton Trans. 13, 1163-1169 (1976).

10. Mingos, D. M. P. Structural and bonding patterns in gold clusters. Dalton Trans. 44, 6680-6695 (2015).

11. Zeller, E., Beruda, H. \& Schmidbaur, H. Tetrahedral gold cluster $\left[\mathrm{Au}_{4}\right]^{2+}$ : crystal structure of $\left\{\left[(\text { tert- } \mathrm{Bu})_{3} \mathrm{PAu}\right]_{4}\right\}^{2+}\left(\mathrm{BF}_{4}^{-}\right)_{2} \cdot 2 \mathrm{CHCl}_{3}$. Inorg. Chem. 32, 3203-3204 (1993)

12. Briant, C. E., Hall, K. P., Mingos, D. M. P. \& Wheeler, A. C. Synthesis and structural characterisation of hexakis(triphenyl phosphine) hexagold $(2+)$ nitrate, $\left[\mathrm{Au}_{6}\left(\mathrm{PPh}_{3}\right)_{6}\right]\left[\mathrm{NO}_{3}\right]_{2}$, and related clusters with edgesharing bitetrahedral geometries. J. Chem. Soc., Dalton Trans. 5, 687-692 (1986).

13. Schulz-Dobrick, M. \& Jansen, M. Intercluster compounds consisting of gold clusters and fullerides: $\left[\mathrm{Au}_{7}\left(\mathrm{PPh}_{3}\right)_{7}\right] \mathrm{C}_{60}$. THF and $\left[\mathrm{Au}_{8}\left(\mathrm{PPh}_{3}\right)_{8}\right]\left(\mathrm{C}_{60}\right)_{2}$. Angew. Chem., Int. Ed. 47, 2256-2259 (2008). 
14. Kamei, Y., Shichibu, Y. \& Konishi, K. Generation of small gold clusters with unique geometries through cluster-to-cluster transformations: octanuclear clusters with edge-sharing gold tetrahedron motifs. Angew. Chem. Int. Ed. Engl. 50, 7442-7445 (2011).

15. Kobayashi, N., Kamei, Y., Shichibu, Y. \& Konishi, K. Protonation-induced chromism of pyridylethynyl-appended [core+exo]-type $\mathrm{Au}_{8}$ clusters. Resonance-coupled electronic perturbation through $\pi$-conjugated group. $J$. Am. Chem. Soc. 135, 16078-16081 (2013).

16. Li, L.-J., Pan, F.-X., Li, F.-Y., Chen, Z.-F. \& Sun, Z.-M. Synthesis, characterization and electronic properties of an endohedral plumbaspherene $\left[\mathrm{Au} @ \mathrm{~Pb}_{12}\right]^{3-}$. Inorg. Chem. Front 4, 1393-1396 (2017).

17. Esenturk, E. N., Fettinger, J. \& Eichhorn, B. The $\mathrm{Pb}_{12}{ }^{2-}$ and $\mathrm{Pb}_{10}{ }^{2-}$ zintl ions and the $\mathrm{M} @ \mathrm{~Pb}_{12}{ }^{2-}$ and $\mathrm{M} @ \mathrm{~Pb}_{10}{ }^{2-}$ cluster series where $\mathrm{M}=\mathrm{Ni}, \mathrm{Pd}, \mathrm{Pt} . J . A m$. Chem. Soc. 128, 9178-9186 (2006).

18. Esenturk, E. N., Fettinger, J., Lam, Y. F. \& Eichhorn, B. $\left[\mathrm{Pt} @ \mathrm{~Pb}_{12}\right]^{2-}$. Angew. Chem. Int. Ed. Engl. 43, 2132-2134 (2004).

19. Yi, W. et al. Synthesis and characterization of the endohedral plumbaspherene $\left[\mathrm{Rh} @ \mathrm{~Pb}_{12}\right]^{3-}$. Chin. J. Struct. Chem. 34, 1253-1258 (2015).

20. Li, A.-M. et al. Endohedral plumbaspherenes of the group 9 metals: synthesis, structure and properties of the $\left[\mathrm{M} @ \mathrm{~Pb}_{12}\right]^{3-}(\mathrm{M}=\mathrm{Co}, \mathrm{Rh}, \mathrm{Ir})$ ions. Chem. Eur. J. 26, 5824-5836 (2020).

21. Zhou, B., Kramer, T., Thompson, A. L., McGrady, J. E. \& Goicoechea, J. M. A

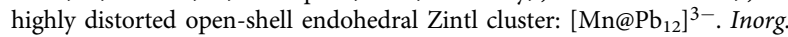
Chem. 50, 8028-8037 (2011).

22. Spiekermann, A., Hoffmann, S. D. \& Fassler, T. F. The Zintl Ion $\left[\mathrm{Pb}_{10}\right]^{2-}: \mathrm{a}$ rare example of a homoatomic closo cluster. Angew. Chem. Int. Ed. Engl. 45, 3459-3462 (2006).

23. Esenturk, E. N., Fettinger, J. \& Eichhorn, B. The closo- $\mathrm{Pb}_{10}{ }^{2-}$ Zintl ion in the $\left[\mathrm{Ni} @ \mathrm{~Pb}_{10}\right]^{2-}$ cluster. Chem. Commun. 2, 247-249 (2005).

24. Sun, Z. M., Xiao, H., Li, J. \& Wang, L. S. $\mathrm{Pd}_{2} @ \mathrm{Sn}_{18}{ }^{4-}$ : fusion of two endohedral stannaspherenes. J. Am. Chem. Soc. 129, 9560-9561 (2007).

25. Goicoechea, J. M. \& Sevov, S. C. $\left[(\mathrm{Ni}-\mathrm{Ni}-\mathrm{Ni}) @\left(\mathrm{Ge}_{9}\right)_{2}\right]^{4-}$ : a linear triatomic nickel filament enclosed in a dimer of nine-atom germanium clusters. Angew. Chem. Int. Ed. 44, 4026-4028 (2005).

26. Lips, F., Clérac, R. \& Dehnen, S. $\left[\mathrm{Pd}_{3} \mathrm{Sn}_{8} \mathrm{Bi}_{6}\right]^{4-}$ : a 14-vertex $\mathrm{Sn} / \mathrm{Bi}$ cluster embedding a $\mathrm{Pd}_{3}$ triangle. J. Am. Chem. Soc. 133, 14168-14171 (2011).

27. Spiekermann, A., Hoffmann, S. D., Kraus, F. \& Fässler, T. F. $\left[\mathrm{Au}_{3} \mathrm{Ge}_{18}\right]^{5-}$ - a gold-germanium cluster with remarkable Au-Au interactions. Angew. Chem. Int. Ed. Engl. 46, 1638-1640 (2007).

28. Mingos, D. M. P. Polyhedral skeletal electron pair approach. Acc. Chem. Res. 17, 311-319 (1984).

29. Pyykko, P. Additive covalent radii for single-, double-, and triple-bonded molecules and tetrahedrally bonded crystals: a summary. J. Phys. Chem. A 119, 2326-2337 (2015).

30. Pan, F.-X. et al. An all-metal aromatic sandwich complex $\left[\mathrm{Sb}_{3} \mathrm{Au}_{3} \mathrm{Sb}_{3}\right]^{3-}$. J. Am. Chem. Soc. 137, 10954-10957 (2015).

31. Shichibu, Y., Zhang, M., Kamei, Y. \& Konishi, K. $\left[\mathrm{Au}_{7}\right]^{3+}$ : a missing link in the four-electron gold cluster family. J. Am. Chem. Soc. 136, 12892-12895 (2014).

32. Kester, J. G. et al. Synthesis and properties of copper and nickel complexes of the general formula $\left(\mathrm{B}_{11} \mathrm{H}_{11}\right)_{2} \mathrm{Mn}^{-}$. Crystal structure of $\left[(\mathrm{n}-\mathrm{Bu})_{4} \mathrm{~N}\right]_{3}[\mathrm{Cu}$ $\left(\mathrm{B}_{11} \mathrm{H}_{11}\right)_{2}$. Inorg. Chem. 33, 5438-5442 (1994).

33. Harvey, J. N. DFT computation of relative spin-state energetics of transition metal compounds. Struct. Bond. 112, 151 (2004).

34. Swart, M. Spin states of (bio)inorganic systems: successes and pitfalls. Int. J. Quant. Chem. 113, 2 (2013).

35. Te Velde, G. et al. Chemistry with ADF. J. Comput. Chem. 22, 931-967 (2001).

36. Fonseca Guerra, C., Snijders, J. G., Te Velde, G. \& Baerends, E. J. Towards an order-N DFT method. Theor. Chem. Acc. 99, 391-403 (1998).

37. ADF2016, SCM, Theoretical Chemisty (Vrije Universiteit, Amsterdam, The Netherlands, 2016).

38. Perdew, J. P., Burke, K. \& Ernzerhof, M. Generalized gradient approximation made simple. Phys. Rev. Lett. 77, 3865-3868 (1996).

39. van Lenthe, E. \& Baerends, E. J. Optimized Slater-type basis sets for the elements 1-118. J. Comp. Chem. 24, 1142-1156 (2003).
40. van Lenthe, E., Baerends, E. J. \& Snijders, J. G. Relativistic regular twocomponent Hamiltonians. J. Chem. Phys. 99, 4597-4610 (1993).

41. van Lenthe, E., Baerends, E. J. \& Snijders, J. G. Relativistic total energy using regular approximations. J. Chem. Phys. 101, 9783-9792 (1994).

42. van Lenthe, E., Ehlers, A. E. \& Baerends, E. J. Geometry optimization in the Zero Order Regular Approximation for relativistic effects. J. Chem. Phys. 110, 8943-8953 (1999).

43. Pye, C. C. \& Ziegler, T. An implementation of the conductor-like screening model of solvation within the Amsterdam Density Functional package. Theor. Chem. Acc. 101, 396-408 (1999).

44. Versluis, L. \& Ziegler, T. The determination of molecular structure by density functional theory. J. Chem. Phys. 88, 322-328 (1988).

45. Ziegler, T. \& Rauk, A. On the calculation of bonding energies by the Hartree Fock Slater method. I. The transition state method. Theor. Chim. Act. 46, 1-10 (1977).

46. Nalewajski, R. F., Mrozek, J. \& Michalak, A. Two-electron valence indices from the Kohn-Sham orbitals. Int. J. Quant. Chem. 61, 589-600 (1997).

\section{Acknowledgements}

The relevant work was supported by the National Natural Science Foundation of China (21971118 and 21722106 to Z.-M.S.). H.W.T.M. thanks the EPSRC for support through the Centre for Doctoral Training, Theory and Modeling in Chemical Sciences under Grant EP/L015722/1.

\section{Author contributions}

Z.-M.S. and J.E.M conceived the project. Z.-M.S. designed the experiments. C.-C.S. conducted the synthesis and C.-C.S. and L.Q. performed the crystallography. J.E.M and H.W.T.M. performed the quantum chemical calculations and analyzed the data. All authors co-wrote the manuscript.

\section{Competing interests}

The authors declare no competing interests.

\section{Additional information}

Supplementary information is available for this paper at https://doi.org/10.1038/s41467 020-17187-4.

Correspondence and requests for materials should be addressed to J.E.M. or Z.-M.S.

Peer review information Nature Communications thanks the anonymous reviewer(s) for their contribution to the peer review of this work. Peer reviewer reports are available.

Reprints and permission information is available at http://www.nature.com/reprints

Publisher's note Springer Nature remains neutral with regard to jurisdictional claims in published maps and institutional affiliations.

Open Access This article is licensed under a Creative Commons Attribution 4.0 International License, which permits use, sharing, adaptation, distribution and reproduction in any medium or format, as long as you give appropriate credit to the original author(s) and the source, provide a link to the Creative Commons license, and indicate if changes were made. The images or other third party material in this article are included in the article's Creative Commons license, unless indicated otherwise in a credit line to the material. If material is not included in the article's Creative Commons license and your intended use is not permitted by statutory regulation or exceeds the permitted use, you will need to obtain permission directly from the copyright holder. To view a copy of this license, visit http://creativecommons.org/ licenses/by/4.0/.

(C) The Author(s) 2020 